\title{
Taman Restoratif: Kriteria Desain Taman untuk Mengurangi Tingkat Stress Pengunjung
}

\author{
Jasmine C. U. Bachtiar ${ }^{1 *}$, Hanson E. Kusuma ${ }^{2}$, Zaedar Gazalba ${ }^{1}$ \\ ${ }^{1}$ Program Studi Arsitektur, Fakultas Teknik, Universitas Mataram \\ Jalan Majapahit No.62, Mataram, NTB, Indonesia \\ ${ }^{2}$ Kelompok Keahlian Perancangan Arsitektur, Asitektur, SAPPK, ITB \\ Labtek IXB, Jalan Ganesha No.10, Bandung, Jawab Barat, Indonesia \\ *Email: jcubachtiar@gmail.com
}

\begin{abstract}
Abstrak
Taman-taman kota adalah sarana rekreasi yang dapat memberikan banyak manfaat, salah staunya yaitu untuk mengurangi stres setelah lelah bekerja. Akan tetapi, beberapa taman tidak dikunjungi karenadi dalamnya terasa snagat gelap sehingga banyak taman yang tidak terawat dan sepi pengunjung. Penelitian ini bertujuan untuk mengetahui bagaimana perbandingan persepsi pengunjung taman pada tingkat tertertutupan berbeda berdasarkan rasa aman dan restorasi yang diterimanya. Penelitian ini bersifat eksperimental sehingga responden diminta untuk menilai beberapa foto yang sudah diedit untuk mengetahui kombinasi ketertutupan yang optimal. Pengumpulan data dilakukan dengan membagikan kuesioner secara daring selama dua minggu $(\mathrm{N}=272)$. Selanjutnya, data diolah melalui uji ANOVA untuk melihat kombinasi ketertutupan yang dinilai paling tinggi dan paling rendah berdasarkan rasa aman dan restorasi. Hasil menunjukkan bahwa rasa aman pengunjung dapat dicapai dengan menerapkan kombinasi ketertutupan 8 (kepadatan tinggi, posisi jauh, skala sedang (6 meter)) dan 9 (kepadatan sedang, posisi dekat, skala tinggi (9 meter)), sementara restorasi yang dirasakan pengunjung cenderung sama dan tidak terikat dengan perbedaan kombinasi ketertutupan. Implementasi pengetahuan ini pada desain taman yaitu menjadikan penataan pepohonan di taman semakin terarah untuk meningkatkan partisipasi penduduk mengunjungi taman. Taman yang sering dikunjungi adalah taman yang berkelanjutan, sehingga menjaga taman dapat dimulai dari penerapan desain taman yang baik.
\end{abstract}

Kata kunci: kepadatan pohon, ketertutupan, posisi pohon, skala pohon, taman kota

\begin{abstract}
Urban parks are public recreational facilities that can provide many benefits, reducing stress from fatigue. However, some urban parks are not frequently visited because it feels very dark inside so that many parks are unkempt and empty of visitors. This study aims to determine how the comparison of park visitors' perceptions at different levels of closure based on the sense of security and restoration they received. This research is experimental in nature, so respondents are asked to rate several edited photos to determine the optimal combination of closure. Data was collected by distributing questionnaires online for two weeks $(N=272)$. Furthermore, the data were processed through the ANOVA test to see which combination of enclosure was rated the highest and the lowest based on perceived savety and restoration. The results show that visitors' perceived safety can be achieved by applying a combination of closeness 8 (high density, far position, medium scale (6 meters)) and 9 (medium density, close position, high scale (9 meters)), while visitors' perceived restoration tends to the same and not tied to different combinations of closure. The implementation of this study is how to design the tree enclosure in urban parks to increase the participation of residents visiting the park. Urban parks that are frequently visited will be sustainable in future, so maintaining parks can be started from designing enclosure of parks.
\end{abstract}

Keywords: tree density, enclosure, tree arrangement, tree scale, urban park

\section{Pendahuluan}

Beberapa tahun terakhir, Pemerintah Daerah memiliki ketertarikan dalam mengembangkan area hijau kota menjadi area fungsional yang dapat digunakan sebagai ruang publik. Beberapa Ruang Terbuka Hijau (RTH) diolah menjadi taman-taman kota yang dilengkapi dengan fasilitas sehingga pengunjung dapat berjalan kaki, berkumpul, refreshing, dan sebagainya di hari kerja dan libur
(Novitasari \& Navastara, 2017). Akan tetapi, perawatan taman-taman kota tidak menjadi perhatian utama. Hal ini menyebabkan program untuk membangun area hijau hanya sebatas desain taman tanpa adanya timbal balik dari hasil desain taman yang telah digunakan. Akibatnya, beberapa taman memiliki fasilitas yang tidak terawat dengan baik, vandalisme di area taman yang sepi (Utaminingtyas et al., 2012), dan berbagai aksi lainnya. Kegiatan tersebut dapat disebabkan oleh lingkungan di dalam 
dan sekitar taman yang mendukung berbagai kegiatan yang tidak baik, seperti pencahayaan yang tidak cukup akibat desain lanskap yang tidak tertata rapi, tingginya densitas pepohonan (Jansson et al., 2013), dan penerangan lampu yang tidak memadai pada malam hari (Nugroho et al., 2017). Beberapa hal tersebut menyebabkan taman-taman kota yang seharusnya menjadi tempat rekreasi menjadi tempat yang tidak ingin dikunjungi.

Sementara itu, keberadaan taman di tengah kota sangat diperlukan sebagai sarana rekreasi untuk mengurangi tingkat stress penduduk selain sebagai RTH kota. Selain taman, hutan kota juga digunakan sebagai sarana rekreasi untuk meredakan stres. Taman dan hutan kota memiliki faktor hijau yang memiliki kemampuan untuk menghilangkan stres pengunjung dengan cara menghambat direct attention menjadi indirect attention melalui elemen-elemen lanskap (Kaplan \& Kaplan, 1989). Pepohonan, rerumputan, semak-semak, air, (Nordh et al., 2009) dan juga bunga (Lindal \& Hartig, 2015) adalah beberapa elemen lanskap yang dapat membuat seseorang merasa segara kembali setelah berlamalama di area hijau. Di dalam environmental psychology, Kaplan \& Kaplan (1989) menjelaskan bahwa seseorang dapat merasa segar kembali karena merasakan perceived restorativeness di area hijau. Perceived restorativeness dinilai berdasarkan empat faktor (Kaplan \& Kaplan, 1989) yaitu: 1) fascination, lingkungan yang menarik dan menggairahkan; 2) being away, perasaan bebas dari kegiatan rutinitas yang membosankan; 3) extent, keterhubungan antar elemen di lanskap; dan 4) compatibility, kesesuaian antara tempat dengan aktivitas yang ingin dilakukan seseorag. Keempat faktor tersebut harus ada di dalam lingkungan dan dirasakan oleh pengunjung untuk mendapatkan restorasi maksimal.

Akan tetapi, tidak semua area hijau memiliki restorasi dengan kualitas yang sama. Ada area hijau yang dipersepsikan menyeramkan sehingga seseorang menjadi stres dan takut ketika berada di dalamnya (Gatersleben \& Andrews, 2013). Ada juga area hijau yang terlalu terbuka dengan pepohonan yang jarang yang mengakibatkan rendahnya preferensi pengunjung ke lingkungan tersebut, sehingga lingkungan dengan densitas pepohonan sedang lebih disukai (Bjerke et al., 2006). Perbedaan kualitas lingkungan tersebut menunjukkan bahwa keamanan memiliki peran dalam menentukan tingkat restorasi dan preferensi kunjungan taman-taman kota. Keamanan yang dirasakan pengunjung dipengaruhi oleh faktor cahaya (Stamps III, 2005a), ketertutupan lingkungan (Stamps III, 2005b), dan keberadaan orang lain (Staats et al., 2016). Diantara ketiga faktor tersebut, ketertutupan lingkungan adalah faktor spasial yang dapat diintervensi arsitek dalam mendesain taman-taman kota. Ketertutupan pepohonan di taman berkaitan dengan faktor lainnya berupa pencahayaan dan kemampuan visual pengunjung dalam melihat area sekitar. Kemampuan melihat dibagi menjadi dua, yaitu prospect (dapat melihat area sekitar) dan refuge (tidak ada area untuk bersembunyi) (Appleton, 1984). Lingkungan dengan prospect tinggi dan refuge rendah lebih disukai karena dapat memberikan rasa aman (Gatersleben \& Andrews, 2013).

Kualitas spasial taman yang berkaitan dengan keamanan adalah ketertutupan pepohonan. Ketertutupan didefinisikan sebagai derajat area sekitar dan kemampuan seseorang untuk menembus sesuatu (Stamps III, 2005a). Faktor-faktor yang merupakan parameter ketertutupan ada banyak, beberapa diantaranya adalah penataan, skala, dan kepdatan. Penataan berkaitan erat dengan keberadaan pepohonan. Salah satu penelitian terdahulu menyatakan bahwa peletakan pohon di salah satu jalan lebih disukai dibandingkan di kedua sisi karena persepsi ketertutupannya menjadi lebih rendah (Jansson et al., 2013) walau beberapa penelitian lainnya menunjukkan peletakan di kedua sisi lebih baik. Skala berhubungan dengan tinggi atau rendahnya pohon dan ketertutupan yang tinggi terlihat pada skala yang tinggi (Stamps III, 2011). Sementara itu, kepadatan pohon dapat dinilai dari jumlah pepohonan di suatu area atau tertutup tidaknya bagian bawah pohon (understorey). Kepadatan yang tinggi memiliki restorasi lebih tinggi dibandingkan dengan kepadatan rendah (Chiang et al., 2017; Jiang et al., 2014).

Penelitian ini dilakukan untuk mengetahui kombinasia desain ketertutupan pepohonan di taman berdasarkan persepsi keamanan dan restorasi pengunjung taman. Hasil penelitian ini diharapkan dapat diterapkan langsung pada taman-taman kota sehingga taman-taman kota dapat memberikan fungsi restorasi maksimal untuk pengunjung taman.

\section{Metode Penelitian}

\section{Metode Pengumpulan Data}

Data penelitian berupa foto taman-taman di Kota Bandung dikumpulkan untuk dinilai oleh responden. Taman terpilih sebagai objek studi adalah Taman Maluku, Taman Lalu Lintas, dan Taman Cilaki yang telah dipilih sebelumnya berdasarkan kriteria elemen lanskap, tingkat ketertutupan tamanan, dan keberadaan jalur sirkulasi. Taman-taman terpilih kemudian diseleksi kembali untuk menentukan titiktitik yang memiliki ketertutupan sama secara visual. Penentuan ini berdasarkan gelap terangnya area taman dan juga komponen elemen lanskap di dalam satu titik yang tertangkap kamera. Dalam proses seleksi, titik yang terpilih di setiap taman adalah dua titik sehingga total titik dalam penelitian ini berjumlah enam titik. 


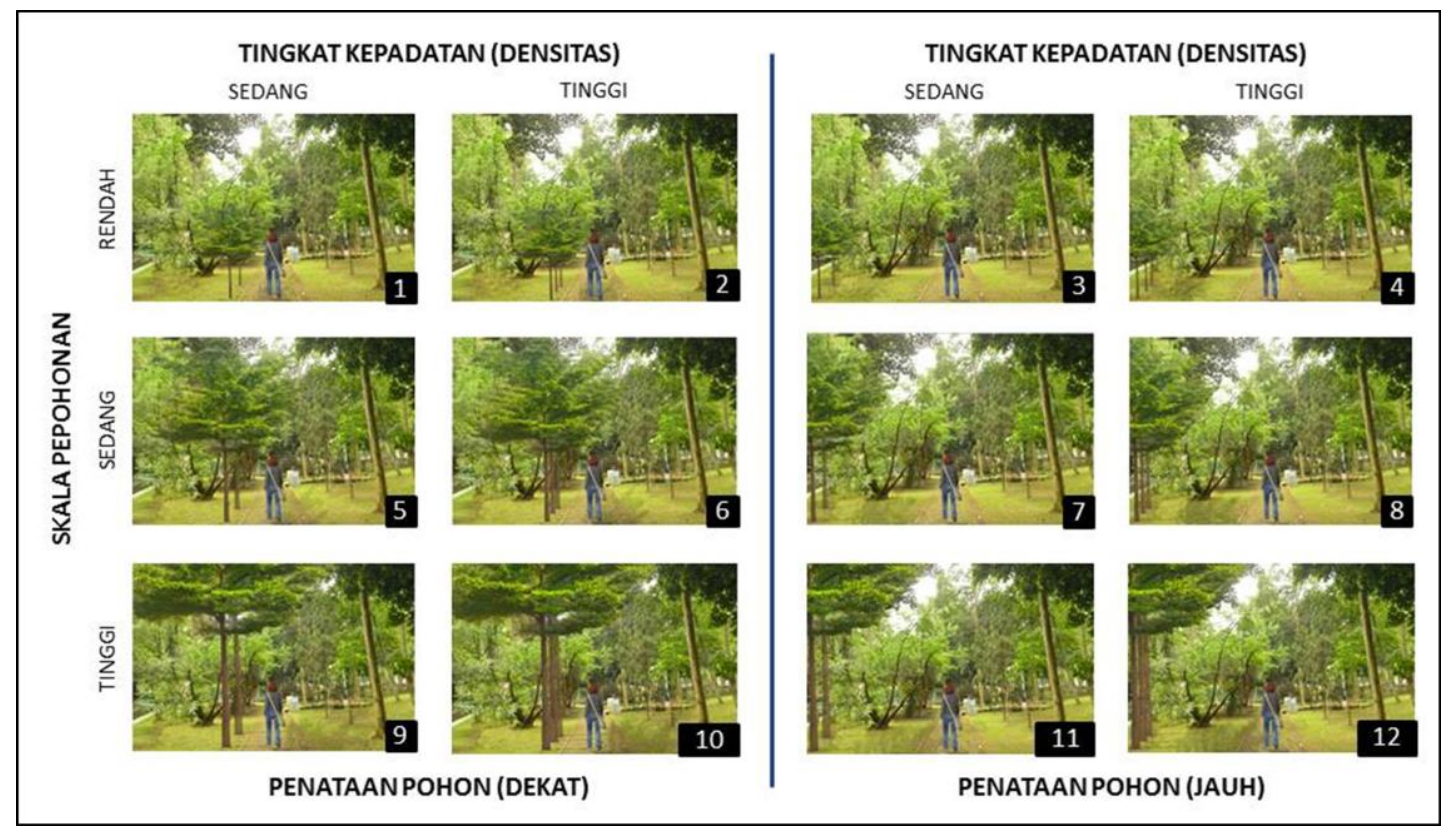

Gambar 1. 12 kombinasi rekayasa parameter ketertutupan

Setelah itu, foto-foto tersebut dikumpulkan untuk direkayasa dengan menambahkan pepohonan di setiap foto terpilih. Kombinasi pepohonan mengikuti tiga faktor ketertutupan yaitu berdasarkan densitas (kepadatan), posisi terhadap jalur sirkulasi, dan skala pepohonan. Untuk densitas, parameter yang digunakan adalah jumlah pepohonan dengan 'tinggi' untuk tiga pohon tambahan dan 'sedang' untuk dua pohon tambahan di dalam satu foto. Sementara itu, parameter untuk posisi pohon yaitu 'dekat' untuk jarak pohon sekitar 20-30 cm dari jalur sirkulasi dan 'jauh' untuk jarak pohon sekitar 80-100 cm dari jalur sirkulasi. Skala pepohonan memiliki tiga parameter utama dengan 'rendah' untuk skala pohon $300 \mathrm{~cm}$, 'sedang' untuk skala pohon $600 \mathrm{~cm}$, dan 'tinggi' untuk skala pohon $900 \mathrm{~cm}$ dari muka tanah. Oleh karena itu, penelitian ini menggunakan 12 kombinasi parameter ketertutupan pepohonan (Tabel 1) untuk komparasi perbedaan persepsi ketertutupan di dalam taman.

Tabel 1. Kombinasi Parameter Ketertutupan Pepohonan

\begin{tabular}{ccccc}
\hline Kombinasi & Densitas & Posisi & Skala & Jumlah \\
\hline 1 & Sedang & Dekat & Rendah & 138 \\
2 & Tinggi & Dekat & Rendah & 137 \\
3 & Sedang & Jauh & Rendah & 137 \\
4 & Tinggi & Jauh & Rendah & 129 \\
5 & Sedang & Dekat & Sedang & 132 \\
6 & Tinggi & Dekat & Sedang & 137 \\
7 & Sedang & Jauh & Sedang & 150 \\
8 & Tinggi & Jauh & Sedang & 143 \\
9 & Sedang & Dekat & Tinggi & 130 \\
10 & Tinggi & Dekat & Tinggi & 133 \\
11 & Sedang & Jauh & Tinggi & 136 \\
12 & Tinggi & Jauh & Tinggi & 124 \\
\hline Total & & & & 1626 \\
\hline
\end{tabular}

Kombinasi-kombinasi ketertutupan tersebut kemudian diaplikasikan ke dalam foto-foto titik taman terpilih (Gambar 1). Selanjutnya, responden akan menilai foto titik taman yang telah direkayasa sebanyak enam kombinasi acak dari enam tamantaman Kota Bandung. Data responden yang terkumpul berjumlah 272 orang dengan data kombinasi pepohonan yang dinilai sebanyak 1626 data. Sekitar 50\% dari jumlah responden adalah mahasiswa, sisanya sebagai dosen, professional, PNS, dan lainnya. Selain itu, sekitar $60 \%$ responden memiliki pendidikan terakhir sarjana, sekitar $15 \%$ SMA, sekitar 25\% SD dan SMP, dan lainnya. Kunjungan responden ke taman-taman kota beragam, lebih dari 50\% responden mengunjungi taman sekitar 1-2 jam, ada yang kurang dari 1 jam, 2-3 jam, dan sangat sedikit yang menghabiskan waktu lebih dari 3 jam. Selanjutnya, data-data responden diolah untuk dianalisis secara statistik.

\section{Metode Analisis Data}

Data yang telah terkumpul secara luring dan daring selanjutnya dianalisis untuk mengetahui bagaimana perseptual pengunjung terhadap ruang. Analisis data dilakukan dengan menggunakan one way anova untuk mengetahui perbedaan persepsi responden pada setiap kombinasi titik yang berbeda. Hasil anova antara ketertutupan dnegan keamanan dan restorasi akan menunjukkan kriteria desain taman yang tepat dan aplikatif untuk ke depannya. Analisis anova dilakukan dengan program JMP versi 13 dan hasil analisis anova ditampilkan dalam bentuk diagram.

Untuk mengetahui hasil akurasi perbedaan setiap kombinasi parameter ketertutupan tersebut, uji Tukey digunakan setelah uji Anova dilakukan. Hasil uji Tukey berupa pengelompokan tipe kombinasi 
berdasarkan perbedaan-perbedaan yang signifikan terhadap semua kombinasi. Hasil akhir uji Anova dan Tukey akan menunjukkan kombinasi ketertutupan yang paling tepat untuk desain taman.

\section{Hasil dan Diskusi}

\section{Kombinasi Ketertutupan Pepohonan untuk Keamanan di dalam Taman}

Persepsi rasa aman di taman dipengaruhi oleh bagaimana keadaan lingkungan di sekitar pengunjung. Berdasarkan hasil uji Anova (Gambar 2), pengunjung memiliki persepsi yang berbeda pada kombinasi ketertutupan taman pada perbedaan yang signifikan ( $\mathrm{P}$ value 0.0070). Kombinasi 1 dan 2 memiliki nilai rata-rata yang lebih rendah dibandingkan dengan kombinasi lainnya. Kombinasi 1 adalah densitas pepohonan sedang, peletakan posisi pohon dekat degan sirkulasi jalan, dan skala pepohonan rendah. Sementara itu, kombinasi 2 memiliki kriteria yang sama dengan kombinasi 1 namun dengan densitas pepohonan tinggi. Berdasarkan hasil uji Anova, kombinasi ketertutupan pepohonan yang dirasa paling tidak aman adalah kombinasi 1 dan 2 diantara kombinasi lainnya.

Sementara itu, secara sekilas, kombinasi ketertutupan yang paling menunjang rasa aman pengunjung tidak terlihat secara jelas, berbeda dengan kombinasi 1 dan 2. Kombinasi yang berada di atas penialian rata-rata adalah kombinasi 7, 8, 9, dan 12. Kombinasi tersebut dinilai memiliki keamanan yang baik walau dianggap tidak jauh berbeda dengan kombinasi ketertutupan lainnya.

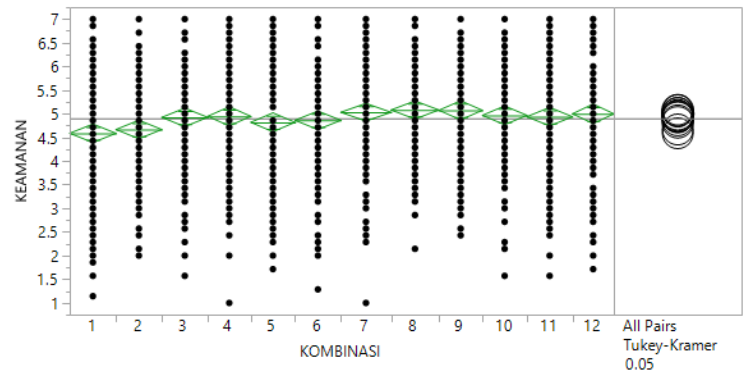

Gambar 2. Hasil uji Anova ketertutupan pohon dan rasa aman responden

Oleh karena itu, uji Anova menunjukkan adanya perbedaan penilaian keamanan pada kombinasi ketertutupan taman. Kombinasi 1 dan 2 adalah kombinasi yang berada di bawah garis rata-rata penilaian semua kombinasi sehingga keduanya dianggap memiliki keamanan yang rendah dibandingkan yang lainnya. Sementara itu, kombinasi yang berada di atas rata-rata penilaian adalah kombinasi 7, 8, 9, dan 12. Akan tetapi, kombinasi tersebut tidak terlihat perbedaannya secara signifikan pada diagram Anova.
Untuk mengetahui perbandingan antar kombinasi ketertutupan pepohonan, uji Tukey dilakukan setelah uji Anova. Uji Tukey menunjukkan bahwa di dalam hubungan antara kombinasi ketertutupan dan keamanan terdapat dua kelompok yang berbeda, yaitu kelompok A dan B (Tabel 2). Kombinasi 8 dan 9 termasuk dalam kelompok A saja sehingga keduanya dianggap berbeda dibandingkan dengan kombinasi lainnya. Sementara itu, kombinasi 1 saja yang termasuk dalam kelompok B. Hal ini menunjukkan bahwa kombinasi 8 da 9 dinilai lebih memiliki rasa aman dan kombinasi 1 dianggap lebih tidak memiliki rasa aman di dalam taman.

Tabel 2. Hasil Uji Tukey Kombinasi Ketertutupan dan Keamanan di Taman

\begin{tabular}{cccc}
\hline Kombinasi & \multicolumn{2}{c}{ Kelompok } & Mean \\
\hline 8 & $\mathrm{~A}$ & & 5.0789211 \\
9 & $\mathrm{~A}$ & & 5.0725275 \\
7 & $\mathrm{~A}$ & $\mathrm{~B}$ & 5.0304762 \\
12 & $\mathrm{~A}$ & $\mathrm{~B}$ & 4.9976959 \\
10 & $\mathrm{~A}$ & $\mathrm{~B}$ & 4.9656284 \\
4 & $\mathrm{~A}$ & $\mathrm{~B}$ & 4.9446290 \\
11 & $\mathrm{~A}$ & $\mathrm{~B}$ & 4.9369748 \\
3 & $\mathrm{~A}$ & $\mathrm{~B}$ & 4.9228363 \\
6 & $\mathrm{~A}$ & $\mathrm{~B}$ & 4.8602711 \\
5 & $\mathrm{~A}$ & $\mathrm{~B}$ & 4.8181818 \\
2 & $\mathrm{~A}$ & $\mathrm{~B}$ & 4.6663191 \\
1 & & $\mathrm{~B}$ & 4.5859213 \\
\hline
\end{tabular}

\section{Kombinasi Ketertutupan Pepohonan untuk Restorasi di dalam Taman}

Restorasi di taman-taman kota dipengaruhi oleh keadaan lingkungan dan juga keadaan yang dirasakan oleh pengunjung saat mengunjungi taman. Berdasarkan uji Anova, restorasi taman di semua kombinasi ketertutupan tidak memiliki perbedaan yang signifikan. Semua kombinasi dianggap memiliki kualitas yang sama. Pada Gambar 3, kombinasi 6 dinilai lebih rendah dibandingkan dengan kombinasi lainnya walau perbedaan penilaian tersebut tidak menunjukkan hasil yang signifikan. Sementara itu, kombinasi lainnya dinilai di atas ratarata total kombinasi.

Tidak adanya perbedaan persepsi restorasi yang diterima responden dapat diakiatkan karena elemen taman yang cenderung sama pada titik tersebut. Di dalam foto, terdapat elemen pepohonan, rerumputan, dan semak belukar yang dianggap memberikan restorasi yang baik (Nordh et al., 2009) sehingga semua responden merasa tidak ada perbedaan di semua foto. Beberapa responden mungkin tidak terlalu mempermasalahkan ketertutupan taman dan menganggap ketertutupan taman yang berbeda bukan bagian dari hal yang perlu diperhatikan saat ingin meredakan stres di dalam taman. 


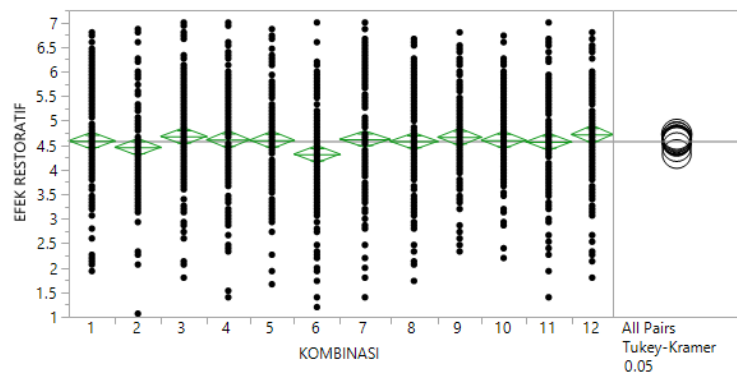

Gambar 3. Hasil uji Anova ketertutupan pohon dan restorasi responden

Untuk memperjelas hasil Anova yang telah dilakukan sebelumnya, uji Tukey dilakukan untuk mengetahui perbedaan tersebut. Hasil uji Tukey menunjukkan bahwa semua kombinasi ketertutupan berada di dalam satu kelompok yang sama (Tabel 3). Hal ini menunjukkan bahwa smeua kombinasi ketertutupan tersebut dinilai tidak memiliki perbedaan yang signifikan walau kombinasi 6 dinilai di bawah ratarata kombinasi total. Oleh karena itu, dapat disimpulkan bahwa perbedaan kombinasi ketertutupan pohon tidak memiliki perbedaan persepsi restorasi di taman kota. Taman kota akan selalu memberikan restorasi walau kondisi taman sangat tertutup ataupun lebih terbuka, akan tetapi elemen-elemen lanskap penunjang restorasi harus ada dan lengkap.

Tabel 3. Hasil Uji Tukey Kombinasi Ketertutupan dan Keamanan di Taman

\begin{tabular}{ccc}
\hline Kombinasi & Kelompok & Mean \\
\hline 12 & A & 4.7220430 \\
3 & A & 4.6817518 \\
9 & A & 4.6656410 \\
7 & A & 4.6231111 \\
4 & A & 4.6144703 \\
5 & A & 4.6060606 \\
10 & A & 4.6045113 \\
1 & A & 4.5908213 \\
8 & A & 4.5818182 \\
11 & A & 4.5700980 \\
2 & A & 4.4613139 \\
6 & A & 4.3197080 \\
\hline
\end{tabular}

\section{Kriteria Ketertutupan Pohon Terbaik untuk Meredakan Stress}

Ketertutupan pohon menunjukkan bagaimana kualitas lingkungan taman dapat memberikan perseptual tertentu kepada pengunjung. Ketertutupan pohon yang sangat tinggi dan lebat mengakibatkan lingkungan menjadi gelap sehingga area taman tampak menyeramkan untuk dilalui. Penelitian ini berusaha untuk mengungkap perbedaan persepsi rasa aman dan restorasi berdasarkan ketertutupan pepohonan yang berbeda-beda. Berdasarkan hasil uji Anova dan Tukey, ketertutupan pepohonan memiliki perbedaan persepsi pada rasa aman namun tidak pada persepsi restorasi responden. Ketertutupan pepohonan yang diuji pada penelitian ini hanya 3 variabel utama yaitu densitas pohon, posisi pohon dari jalur sirkulasi, dan skala pohon. Persepsi restorasi tidak terlihat jelas perbedaannya pada ketertutupan yang berbeda pada penelitian ini, namun tidak menutup kemungkinan ditemukan adanya perbedaan pada penelitian lain yang sejenis.

Kriteria ketertutupan pohon yang terbaik untuk meningkatkan rasa aman di taman dapat ditemukan pada kombinasi ketertutupan pohon 8 dan 9. Kriteria ketertutupan pada kombinasi 8 dan 9 tidak memiliki persamaan kriteria ketertutupan pohon. Akan tetapi, pada Gambar 4, kedua gambar terlihat lapang dengan adanya ruang kosong di sekitar area sirkulasi.

Kombinasi 8 dianggap memiliki rasa aman yang tinggi karena memiliki area yang luas di sekitar sirkulasi utama. Densitas pepohonan yang tinggi walau terletak jauh dari sirkulasi utama dianggap memiliki rasa aman yang rendah pada penelitian sebelumnya (Jorgensen et al., 2002). Akan tetapi, penelitian ini menunjukkan tingginya rasa aman. Hal ini mungkin disebabkan oleh understory (area di bagian batang pohon) penelitian ini tidak terlalu padat seperti penelitian sebelumnya (Jorgensen et al., 2002). Understory yang padat dianggap memiliki rasa aman rendah karena kekhawatiran adanya orang lain yang bersembunyi. Penelitian lain juga mengemukakan bahwa tingkat kepadatan yang tinggi memiliki rasa mencekam dan lebih tidak disukai karena dapat menurunkan visibilitas dan potensi adanya tempat untuk bersembunyi (Gatersleben \& Andrews, 2013). Jadi, densitas pepohonan tinggi dapat memberikan rasa aman jika tidak terlalu padat pada bagian bawah pohon dan terletak jauh dari jalur sirkulasi.

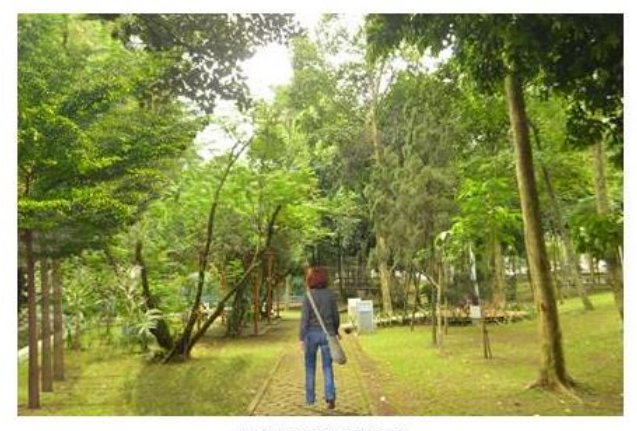

\section{KOMBINASI 8}

Densitas tinggi, posisi pohon jauh dari sirkulasi, dan skala pohon sedang ( 6 meter)

Gambar 4. Kombinasi ketertutupan pohon yang menunjang keamanan di taman

Sementara itu, kombinasi 8 memiliki skala pepohonan sedang (6 meter). Skala tersebut dianggap lebih memberikan rasa aman diabandingkan dengan skala yang tinggi ( 9 meter) dengan kriteria densitas dan posisi yang sama. Penelitian sebelumnya dengan 
metode eksperimental menunjukkan bahwa rumahrumah dengan ketinggian 1 lantai dianggap lebih memberikan rasa restorasi dibandingkan dengan rumah 2 lantai yang lebih tinggi (Lindal \& Hartig, 2013). Hal ini disebabkan oleh bangunan yang tinggi mengurangi being away yang dirasakan oleh responden ketika berjalan di area perumahan. Pada penelitian ini, hal tersebut mungkin juga disebabkan oleh pepohonan dengan tinggi 6 meter dapat memberikan rasa being away ketika berjalan, namun pernyataan ini perlu dibuktikan oleh penelitian baru lainnya.

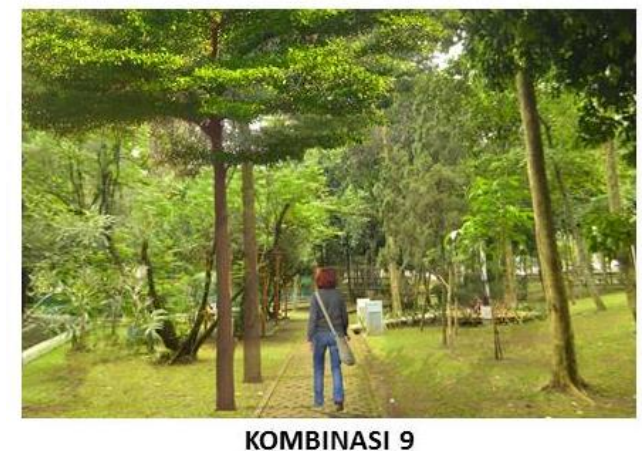

Densitas sedang, posisi pohon dekat dari sirkulasi, dan skala pohon tinggi (9 meter)

Gambar 4. Kombinasi ketertutupan pohon yang menunjang keamanan di taman

Kriteria ketertutupan pada kombinasi 9 memiliki pepohonan densitas sedang yang terletak dekat dengan jalur sirkulasi. Pepohonan yang terletak di dekat jalur sirkulasi membuat area sirkulasi lebih sempit sehingga pandangan ke area sekitar terbatas. Akan tetapi, pada gambar kombinasi 9, area sekitar masih dapat terlihat jelas sehingga prospect ke area skeitar tinggi dan refuge juga rendah. Walau pepohonan dekat dengan sirkulasi, dengan visibilitas yang tinggi, hal tersebut tidak menjadi masalah utama dan mendukung adanya restorasi dengan skala pepohonan tinggi.

Selain itu, kriteria ketertutupan pohon dengan skala pepohonan yang tinggi ( 9 meter) membuat area sekitar sirkulasi dapat terlihat dengan baik. Pepohonan yang tinggi dengan densitas sedang tidak menghalangi cahaya ke area sirkulasi sehingga pepohonan tidak terlihat menakutkan dan memberikan rasa naungan bagi responden atau pejalan kaki. Penelitian terdahulu belum ada yang memiliki perhatian pada tinggi pepohonan pada jalur sirkulasi taman.

Selain kombinasi ketertutupan pepohonan dengan rasa aman yang tinggi, ada satu kombinasi yang dianggap memiliki nilai rendah pada rasa aman. Kombinasi 1 dengan densitas sedang, posisi peletakan pohon dekat dnegan jalur sirkulasi, dan skala pohon rendah (3 meter). Pada Gambar 5, area pandang seseorang terhadap area sekitarnya terhalangi oleh adanya pepohonan di sepanjang sirkulasi sehingga prospect rendah dengan refuge yang tinggi. Penelitian sebelumnya menunjukkan bahwa hutan dengan diri tersebut tidak disukai dan tidak restoratif karena dianggap tidak aman ketika seseorang berjalan di dalamnya (Gatersleben \& Andrews, 2013). Kombinasi 1 dan 2 memiliki kemiripan sehingga besar nilai rata-ratanya tidak terlalu jauh, namun responden lebih banyak memberikan nilai negatif untuk Kombinasi 1.

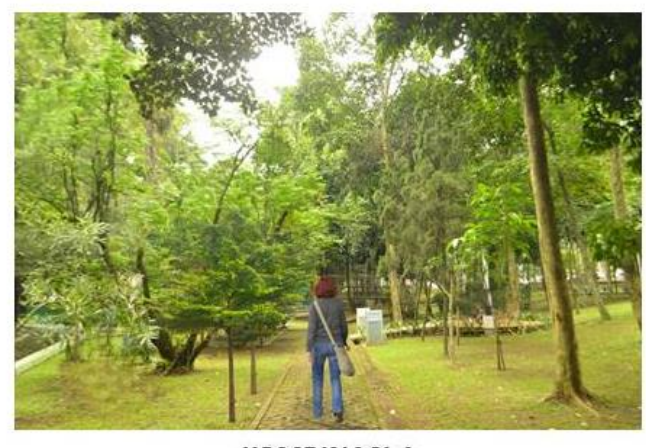

KOMBINASI 1

Densitas sedang, posisi pohon dekat dari sirkulasi, dan skala pohon rendah ( 3 meter)

Gambar 5. Kombinasi ketertutupan pohon yang tidak memberikan keamanan di tamann

Dari pemaparan tersebut, kriteria desain pepohonan di lingkungan alami yang dapat menunjang rasa aman adalah Kombinasi 8 dan 9. Pepohonan dengan densitas tinggi, posisi peletakan pohon dari jalur sirkulasi, dan dengan skala pepohonan sedang (Kombinasi 8) menjadi kriteria desain untuk arsitek lanskap merancang ruang luar. Selain itu, pepohonan dengan densitas sedang, posisi pepohonan dekat dengan jalur sirkulasi, dan skala yang tinggi dapat menjadi alternatif lain dalam medesain taman kota. Kedua kombinasi tersebut berbeda pada seluruh aspek, namun keduanya dapat memberikan rasa aman. Apabila arsitek lanskap memerlukan pepohonan untuk didesain dekat dengan jalur sirkulasi, maka ia dapat menggunakan kombinasi 9, dan sebaliknya.

Sementara itu, tidak ada kombinasi ketertutupan yang dianggap memiliki restorasi tertinggi ataupun terendah di lingkungan alami. Hal ini mungkin disebabkan oleh keadaan lingkungan yang hampir mirip dengan elemen-elemen lanskap yang serupa atau sama. Di dalam gambar kombinasi yang diajukan ke responden, semua gambar memiliki unsur rumput, semak, dan pohon yang merupakan elemen restoratif taman (Nordh et al., 2009) sehingga perbedaan rasa restorasi tidak signifikan antar kombinasi. Hal ini menunjukkan bahwa restorasi di taman cenderung sama dan tidak ada perbedaan walau memiliki komposisi pepohonan yang berbedabeda. Kombinasi pepohonan hanya memiliki perbedaan terhadap rasa aman dan bukan restorasi. 
Penelitian ini belum dapat mengungkapkan hubungan antar ketiga faktor, yaitu ketertutupan, keamanan, dan restorasi sehingga penelitian lebih lanjut perlu dilakukan untuk memetakan hubungan. Penelitian belum dapat membuktikan ada atau tidaknya pengaruh ketertutupan terhadap rasa aman, hanya sebatas pada ada atau tidkanya perbedaan rasa aman dan restorasi pada kombinasi ketertutupan yang berbeda-beda. Penelitian arsitektur di bidang arsitektur lanskap perlu dilakukan untuk mengembangkan kriteria desain taman yang dapat menunjang rasa aman dan restorasi. Taman yang dapat memberikan rasa aman dan restorasi akan mengundang pengunjung untuk datang sehingga taman-taman kota akan berdaya dan ramai dikunjungi. Sustainabilitas taman-taman kota dimulai dari menciptakan taman yang dapat diterima oleh masyarakat ataupun penduduk sekitar taman-taman tersebut. Peran pemerintah, peneliti, dan masyarakat sangat penting dalam sustainabilitas taman-taman kota yang semakin berkurang akibat urbanisasi.

\section{Kesimpulan}

Kombinasi pepohnan di lingkungan alami atau taman kota memiliki perbedaan pada rasa aman. Kombinasi ketertutupan pohon yang dapat diaplikasikan apabila pohon diletakkan jauh dari jalur sirkulasi yaitu pohon memiliki densitas tinggi (rapat) dengan skala pohon sedang (6 meter) (Kombinasi 8). Apabila desain pohon ingin diletakkan dekat dengan jalur sirkulasi, maka pepohonan harus memiliki densitas sedang (tidak rapat) dan skala pepohonan tinggi (Kombinasi 9). Kedua kriteria tersebut menunjang rasa aman karena memiliki prospect yang tinggi dengan refuge yang rendah. Selain itu, entrophy atau ketertutupan dnegan area luar juga lebih rapat sehingga memungkinkan responden untuk mendapatkan rasa restorasi. Akan tetapi, penelitian ini belum dapat mengungkapkan hal tersebut.

Selain itu, penelitian ini juga membuktikan bahwa rasa restorasi tidak ada perbedaan yang mencolok apabila elemen lanskap di setiap gambar sama (rumput, pohon, dan semak). Kombinasi pohon yang berbeda tidak memberikan perbedaan persepsi restorasi di taman-taman kota. Kesamaan area hijau menyebabkan semua kombinasi pohon membiliki nilai restorasi yang cenderung tidak berbeda.

Penelitian ini memiliki beberapa kelebihan dan kekurangan yang dapat dilanjutkan untuk penelitian selanjutnya. Kelebihan penelitian ini adalah adanya upaya dalam mengembangkan metode penilaian pada kualitas desain taman dengan melakukan rekayasa pada objek-objek gambar. Di Indonesia, metode penelitian sejenis belum dilakukan sebelumnya sehingga pengembangan metode seperti ini sangat penting untuk ilmu arsitektur. Kekurangan penelitian adalah belum dapat mengungkap banyak hal seperti hubungan antara ketertutupan pohon dnegan rasa aman dan restorasi, adanya pengaruh pada ketiga faktor tersebut, dan seberapa jauh ketertutupan pohon dapat mempengaruhi rasa aman dan restorasi. Penelitian sejenis diharapkan dapat dilanjutkan ke depannya dengan rumusan dan hipotesis yang lebih baik.

Hasil penelitian ini dapat menjadi kriteria desain aplikatif bagi arsitektur lanskap dna juga pemerintah. Sustainabilitas area hijau kota bukanlah tanggung jawab masyarakat saja, melainkan tanggung jawab perencana taman. Arsitek lanskap bertanggung jawab sebagai perencana dan pengembang desian yang dapat mengundang pengunjung, semnetara pemerintah bertanggung jawab terhadap programprogram taman kota dari kebijakan awal hingga akhir. Area hijau di tengah kota harus dilestarikan untuk kehidupan generasi selanjutnya yang lebih baik dari masa kini.

\section{Daftar Pustaka}

Appleton, J. (1984). Prospects and Refuges Re-Visited. Landscape Journal, 3(2), 91-103.

Bjerke, T., Østdahl, T., Thrane, C., \& Strumse, E. (2006). Vegetation density of urban parks and perceived appropriateness for recreation. Urban Forestry \& Urban Greening, 5, 35-44. https://doi.org/10.1016/j.ufug.2006.01.006

Chiang, Y., Li, D., \& Jane, H. (2017). Wild or tended nature? The effects of landscape location and vegetation density on physiological and psychological responses. Landscape and Urban Planning, 167, 72-83. https://doi.org/10.1016/j.landurbplan.2017.06.001

Gatersleben, B., \& Andrews, M. (2013). When Walking in Nature Is Not Restorative - The Role of Prospect and Refuge. Health \& Place, 20, 91-101. https://doi.org/10.1016/j.healthplace.2013.01.001

Jansson, M., Fors, H., Lindgren, T., \& Wiström, B. (2013). Perceived personal safety in relation to urban woodland vegetation - A review. Urban Forestry \& Urban Greening, 12(2), 127-133. https://doi.org/10.1016/j.ufug.2013.01.005

Jiang, B., Chang, C., \& Sullivan, W. C. (2014). A dose of nature: Tree cover, stress reduction, and gender differences. Landscape and Urban Planning, 132, 26-36.

https://doi.org/10.1016/j.landurbplan.2014.08.005

Jorgensen, A., Hitchmough, J., \& Calvert, T. (2002). Woodland spaces and edges: their impact on perception of safety and preference. Landscape and Urban Planning, 60, 135-150.

Kaplan, R., \& Kaplan, S. (1989). The Experience of Nature: A Psychological Perspective. Cambridge University Press.

Lindal, P. J., \& Hartig, T. (2013). Architectural variation, building height, and the restorative quality of urban 
residential streetscapes. Journal of Environmental Psychology, 33, 26-36. https://doi.org/10.1016/j.jenvp.2012.09.003

Lindal, P. J., \& Hartig, T. (2015). Effects of urban street vegetation on judgments of restoration likelihood. Urban Forestry \& Urban Greening, 14(2), 200-209. https://doi.org/10.1016/j.ufug.2015.02.001

Nordh, H., Hartig, T., Hagerhall, C. M., \& Fry, G. (2009). Components of small urban parks that predict the possibility for restoration. Urban Forestry \& Urban Greening, $\quad 8, \quad 225-235$. https://doi.org/10.1016/j.ufug.2009.06.003

Novitasari, D. F., \& Navastara, A. M. (2017). Karakteristik Pengunjung dan Aktivitasnya Terhadap Peggunaan Taman Kota Sebagai Ruang Sosial di Taman Keplaksari Kabupaten Jombang. Jurnal Teknik ITS, 6(2), 534-538.

Nugroho, H. B. J., Arsi, A. A., \& Akhiroh, N. S. (2017). Perilaku Sosial Remaja dalam Memanfaatkan Ruang Publik Perkotaan (Studi Kasus Pemanfaatan Taman Kota Pleret Banjir Kanal Barat Semarang). Solidarity, 6(1).

Staats, H., Jahncke, H., Herzog, T. R., \& Hartig, T. (2016). Urban Options for Psychological Restoration: Common Strategies in Everyday Situations. PLOS ONE, https://doi.org/10.1371/journal.pone.0146213

Stamps III, A. E. (2005a). Enclosure and Safety in Urbanscapes. Environment and Behavior, 37(102), 102-132. https://doi.org/10.1177/0013916504266806

Stamps III, A. E. (2005b). Isovists , enclosure , and permeability theory. Environment and Palnning B: Planning and Design, 32, 735-762. https://doi.org/10.1068/b31138

Stamps III, A. E. (2011). Effects of boundary height and horizontal size within boundary on perceived enclosure. Perceptual and Motor Skills, 113(3), 995998. https://doi.org/10.2466/24.27.PMS.113.6.995998

Utaminingtyas, A., Astiningsih, A. A. M., \& Mayun, I. A. (2012). Studi Hubungan Vandalisme dengan Setting Taman Lapangan Puputan Badung I Gusti Ngurah Made Agung Denpasar - Bali. Agroekoteknologi Tropika, 1(2), 144-153. 